\title{
Customer loyalty guidelines for independent financial advisers in South Africa
}

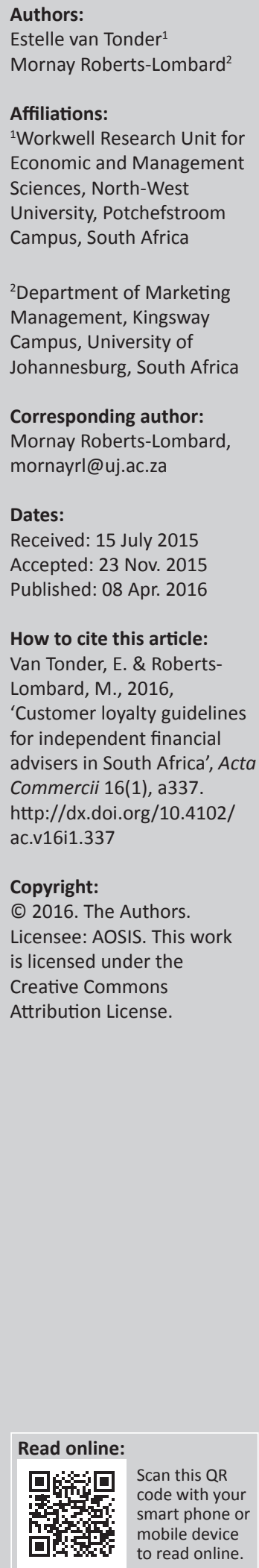

Orientation: Independent financial advisers in South Africa can make a valuable contribution to the financial well-being of the country's citizens and, through sound financial planning and education, assist them in becoming financially independent.

Research purpose: The purpose of this study was to develop guidelines for creating customer loyalty towards independent financial advisers in South Africa.

Motivation: To succeed, financial advisers need to build good relationships with clients and ensure they remain loyal to them in the long term.

Research design, approach and method: A convenience non-probability sampling technique was applied, and altogether 262 self-administered questionnaires were completed and used in the analysis. Descriptive and standard multiple regression analysis and the one-way analysis of variance (ANOVA) technique were used to test four hypotheses formulated for the study.

Main findings: Relationship commitment must be established in a trustworthy environment, regardless of the type of province where the business is operated.

Practical/managerial implications: In urban provinces (such as Gauteng) both trusting relationships and commitment could lead to customer loyalty; in semi-urban provinces (such as North-West) only the commitment variable might do so. Independent financial advisers in both provinces should explore additional factors that could foster customer loyalty.

Contributions: The research findings of this study challenge the seminal work of Morgan and Hunt (1994) by establishing that in South Africa, the extent to which trust and commitment predicts customer loyalty is specific to both industrial and geographical location. This study further provides customer loyalty guidelines for independent financial advisers in South Africa.

\section{Introduction}

The education of South Africans regarding aspects of financial planning is important for building a financially inclusive society. Independent financial advisers could make a valuable contribution in this regard as they can provide clients with customised training to assist them in understanding their financial needs and to plan correctly for the long term. For these advisers to succeed it would, however, be imperative to build good relationships with their clients and ensure that they remain loyal to them over the long term.

Creating long term relationships with customers further requires knowledge of the factors contributing to the establishment and maintenance of such relationships. Various empirical studies have been conducted, most focussing on specific sections of the marketing relationship, such as the impact of satisfaction on trust (Leisen \& Hyman 2004; Liang \& Wang 2007), trust on commitment (Razzaque \& Boon 2003; Tellefsen \& Thomas 2005) and commitment on the intention to stay in a relationship (Abdul-Muhmin 2005; Gounaris 2005), to name just a few. As far as can be ascertained, no comprehensive study of the relevance of the four factors of trust, commitment, customer satisfaction and supplier image for the establishment of long-term marketing relationships in the independent financial adviser industry has been reported before from a South African perspective.

To address this research gap, it was the aim of the study to focus on independent financial advisers in South Africa. Once these factors are considered, independent financial advisers might be in a better position to foster stronger customer loyalty, educate consumers and assist them in creating greater financial wealth over the long term. 


\section{Theoretical overview \\ Relationship marketing in financial services}

Relationship marketing can be viewed as a business approach for establishing and managing the relationships between an organisation and its customer base. It encompasses all the functions of marketing with the purpose of establishing, developing and maintaining relationships with a partner at a profit through mutual exchange and delivery on promises (Egan 2011:266; Harwood, Garry \& Broderick 2008:17).

Higher levels of competitiveness in the market place, increased marketing costs, and shortened technology life cycles necessitate a greater focus on the building of long term relationships with customers (Gilaninia et al. 2011:787). Theron, Terblanche and Boshoff (2012:32) support this argument by proposing that a renewed focus on relationship marketing over the last three decades has provided service organisations with an opportunity to secure a competitive advantage through relationship building initiatives. They argue further that role players in the financial sector have been progressive in their implementation of relationship strategies to strengthen their financial positions.

\section{Relationship marketing and customer loyalty}

Organisations use a relational approach to establish longterm relationships with customers and such an approach should be to the benefit of all parties involved (Rootman, Tait \& Sharp 2011:187). Venetis and Ghauri (2004:1579) confirm that managing long-term relationships is beneficial to all role players involved. From an organisational perspective, the benefits that accrue from such a relationship include a reduction in pricing competition, increased income generation from a customer base in the long term, and the establishment of barriers against competitors (Omar \& Moh 2010:25). It is important to understand that a relational approach towards customers entails more than simply recruiting new customers (Ebersohn \& Theron 2014:3). It also encompasses activities that focus on the management of the customer to enhance customer loyalty. Customers will remain loyal to an organisation if a relationship is established and professionally managed between them and the organisation (Omar \& Moh 2010:25-26). Customer loyalty as such can be viewed as an obligation, based on emotion, to continue purchasing a specific brand of product or service without considering circumstantial influence or promotional efforts to secure switching actions (Rai \& Medha 2013:140).

Literature theorises that factors such as trust, commitment, customer satisfaction, and supplier image are important when assessing customer loyalty (Van Vuuren 2011:18).

\section{Trust}

The marketing literature provides encompassing support for the inclusion of trust in building relationships. Trust exists '... when one party has confidence in an exchange partner's reliability and integrity' (Morgan \& Hunt 1994:23). Jumaev,
Kumar and Hanaysha (2012:41) further argue that trust is a key virtue in relationship building, as it is the basic foundation of a relational approach to ensure that both parties are fully committed to the relationship. Parties to a relationship desire '... predictable and obligatory behaviour' from each other to such an extent that a high level of certainty is linked to future benefits (Negi \& Ketema 2010:115). Parties are also more willing to commit themselves to such a relationship if it is developed from a sound foundation of trust (Morgan \& Hunt 1994:24). Ultimately, trust can be viewed as a precursor to the establishment of customer loyalty and a key element in both the establishment and the management of long-term relationships with customers, supported by actions to deliver on promises made (Rauyruen \& Miller 2007:24). Theron et al. (2012:33) further propose that the '... importance of trust has been confirmed in a variety of sub-industries, such as retail banking (Ndubisi, Wah \& Ndubisi 2007), merchant banking (Liang \& Wang 2007), financial planning (Johnson \& Grayson 2005), electronic banking (Soureli, Lewis \& Karantinou 2008) and asset management (Nijssen \& van Herk 2009)'.

\section{Commitment}

The marketing literature secondly emphasises the role of commitment when a long-term relationship is established. For example, Hunt, Arnett and Madhavaram (2006:78) and Hennig-Thurau, Gwinner and Gremler (2002:232) state that both trust and commitment are required to ensure a partnership approach towards relationship building. Commitment is defined as:

$[A] n$ exchange partner believing that an ongoing relationship with another is so important as to warrant maximum efforts at maintaining it; that is, the committed party believes the relationship is worth working on to ensure that it endures indefinitely. (Morgan \& Hunt 1994:23)

Marketing theorists such as Amin et al. (2011:789) further refer to commitment as an interest by parties to a relationship to remain with a specific course of action out of their own free will. Commitment implies that partners would rather consider the benefits that accrue from establishing a long-term relationship than the short-term benefits available (Read 2009:28). Therefore, commitment relates to an implied or unequivocal promise of continuation between parties to a relationship (Dwyer, Schurr \& Oh 1987:13; Nyadzayo 2010:189). Commitment is a central element in the relationship building process and is a strong foundation for securing a long-term relationship building approach (Rauyruen \& Miller 2007:3; Van Vuuren 2011:80). Morgan and Hunt (1994:5-26) note that commitment must be established within a trustworthy environment. They state that '... relationships characterised by trust are so highly valued that parties will desire to commit themselves to such relationships. Indeed, because relationship commitment entails vulnerability, parties will seek only trustworthy partners'. This argument is supported by Theron, Terblanche and Boshoff (2010b:998-999), who state that commitment can be secured only if a trustworthy environment is created through which parties to a relationship can commit to such a relationship. 


\section{Customer satisfaction}

Customer satisfaction also seems to be a key factor in marketing relationships (Amoako 2012:136; Balas \& Tareef 2011:67; Ha \& Lee 2010:1163; Theron et al. 2012:34).

Customer satisfaction is the consumer fulfilment response. It is a judgment that a product or service feature, or the product or service itself, provided (or is providing) a pleasurable level of consumption-related fulfilment, including levels of under- or over-fulfilment. (Oliver 1997:3)

Halimi, Chavosh and Choshali (2011:51) argue that organisations continuously focus on the satisfaction of customer needs as a precursor for securing their retention. In the current business environment, customer satisfaction has been identified as a priority concern for organisational management in securing future business growth. Therefore, if an organisation wants to survive in an increasingly competitive business environment, the customer must be provided with products and services of superior quality to enhance customer satisfaction levels. This can result in positive word of mouth referrals by the customer ( $\mathrm{Hu}$, Kandampully \& Juhaweer 2009:115). Swar (2012:26) further holds the opinion that the process of service quality management through the continuous assessment of customer satisfaction levels has become a critical element in securing the success of services marketing compared to the marketing of products.

The core focus of services marketing is on satisfying both the needs and the wants of customers. This implies that customer satisfaction has become the pivotal point of all marketing activities (Hu et al. 2009:115). Luo and Homburg (2007:133) support this view and identify customer satisfaction as a key antecedent of customer loyalty. Ndubisi, Malhotra and Chan (2009:8) note that through empirical research it has been scientifically proven that the satisfaction of a customer's needs and wants has a positive influence on the consumer's decision to remain loyal to the relationship. When customers are dissatisfied they are both willing to exit from the relationship and to criticise the business.

\section{Supplier image}

Van Vuuren, Roberts-Lombard and Van Tonder (2012:98) hold the view that the concept of 'supplier image' has not been academically explored in the same manner as concepts such as trust, commitment and customer satisfaction. It is argued that supplier image is a central element in following a long-term relational approach towards a customer. Wang (2010:255) describes supplier image as a total impression made in the mind of an individual by an organisation, whether visually, through communication or in print. Van Vuuren (2011:75) concurs, arguing that supplier image refers to the customer's perception, developed over the long term, of the sum of all experiences from previous interactions with an organisation.

Hoq, Sulatana and Amin (2010:72-73) propose that customer loyalty is influenced by image and that the association between image and loyalty is of a positive nature, and a result of customers' evaluations of the perceived quality of service and product received from the business. They argue that if the experience is of a positive nature, the resulting perception of the organisation will also be positive. Da Silva and Alwi (2008:125) agree and argue that the image communicated by a supplier is a central prerequisite for securing customer loyalty. According to them, the development of loyalty is influenced by the customer's perception (positive or negative) of the image formed by the supplier. Favourable supplier image is important, not only to improve loyalty but also to promote positive word of mouth. Customers need to be aware of a supplier, its products and its services for the correct reasons. Therefore, the management of supplier image is of critical importance as the outcome can be positive or negative if not managed professionally (Friedman, Brown \& Taran 2007:375-376). Supplier image is therefore a key element that influences customer loyalty, and a positive image can encourage customers to purchase more. The loyalty of current customers is also dependent on whether an image is maintained and enhanced (Hu et al. 2009:117).

Supplier image further has both direct and indirect effects on customer loyalty (Hawabhay, Abratt \& Peters 2009:4). An individual's decision-making process is characterised by weighing the costs and benefits of a specific decision. An implication is that as perceived switching costs increase, the costs will offset the perceived benefits of switching to an organisation with a better image. Therefore, despite an increase in switching costs, an unhappy customer may decide to remain loyal to an organisation even though its image has been influenced negatively (Kuo \& Ye 2009:752-753). Hence, there will be an insignificant relationship between supplier image and customer loyalty in cases of high switching costs. In comparison, in the case of low switching costs, customers with a negative perception of an organisation's image will have greater motivation to leave the organisation, which strengthens the relationship between supplier image and customer loyalty (Wang 2010:255).

\section{Perceptions of racial groups}

Struwig, Roberts and Gordon (2013:viii) state that 25\% of South Africans in 2012 indicated that they assumed sole personal responsibility for daily money management in the household in which they reside. It was furthermore determined in the same study that:

$[A]$ population group difference was identified with only half of married Black Africans reporting sharing financial household decision-making with their partner compared with $63 \%$ of married Coloured South Africans and 70\% of married White South Africans. This may indicate cultural differences in the way daily household decisions are made. (p. viii)

In terms of financial planning it was established that mixed race and black South Africans ranked the lowest in terms of financial knowledge, saving and planning for retirement. The white and Indian population in South Africa ranked the highest for this category. It is therefore argued that after 
20 years of democracy, education on issues of financial planning is still determined by socio-economic standing, influencing access to education which imparts changing behaviour (Struwig et al. 2013:91, 98). Joffe (2010:4-5) states that the financial service delivery process should be guided by the principles of trust, created through product knowledge, empathy and the service scape itself. Addressing these aspects fully in the service delivery process will lead to the commitment and the eventual loyalty of the customer. Joffe further argues that this approach should be generic to all customer levels, irrespective of the customer portfolio.

\section{Perceptions of geographic regions}

South Africa has experienced rapid urbanisation since 2000, similar to most other emerging economies in the world (Zuma 2013:3). A total of 75\% of South Africa's population currently resides in the urban regions of the country. The number of South Africans living in urban or semi-urban parts of the country has increased from 52\% in 1990 to $62 \%$ in 2011 (South Africa Info 2013). The Gauteng province of South Africa is the smallest province and represents only $1.4 \%$ of the total geographical land area of the country. The province is primarily urban with a total number of 12 million citizens within its borders (South Africa Info 2015a). The North-West province is South Africa's 4th-smallest province, consisting of $8.7 \%$ of South Africa's land area with a population of 3.5 million people. The province is characterised by both semi-urban and rural areas, with Potchefstroom, Klerksdorp and Mafikeng the major semi-urban areas (South Africa Info 2015b).

A Financial Services Board (FSB) survey conducted in 2012 illustrated that aspects such as race, level of education, income level and the geographical area of residence play a central role in South African's financial literacy levels. The report specified that differences in financial literacy are evident amongst black South Africans relative to other population groups, with the former having lower levels of financial literacy. Disparity in terms of financial knowledge is also evident between rural, semi-urban and urban populations and South Africans residing in provinces such as the Eastern Cape, Limpopo and North-West have lower levels of financial control compared to individuals living in Gauteng or the Western Cape province (Roberts et al. 2012:7; Struwig et al. 2013:xvi, 41, 97). In conclusion, South Africans living in provinces with a higher level of economic employment, educational literacy and urbanisation record (e.g. Gauteng, Western Cape and Kwazulu-Natal) illustrate a higher level of financial literacy compared to provinces such as the Eastern Cape, North-West and Limpopo (Struwig et al. 2013:35).

Accordingly, following the literature investigation, it is hypothesised in this article that:

- HA $^{1}$ : All four independent variables can be viewed as predictors of customer loyalty towards independent financial advisers in the Gauteng and North-West provinces of South Africa.
- HA$^{2}$ : All four independent variables have an equal significant positive relationship with customer loyalty towards independent financial advisers in the Gauteng and North-West provinces of South Africa.

- HA $^{3}$ : There is a significant difference between the perceptions of Gauteng and North-West respondents with respect to all the independent variables and the dependent variable customer loyalty.

- HA$^{4}$ : There are significant differences between the perceptions of the various racial groups with respect to all the variables investigated.

\section{Methodology}

The researchers followed an exploratory and quantitative design to conduct the survey. The population of the study comprised all clients of independent financial advisers in the Gauteng and North-West provinces of South Africa. The Gauteng province was selected because of the fact that it represents an urban area and can be regarded as the economic hub of South Africa. The North-West province was chosen because it is situated in a semi-urban area in the country. The study of these two provinces would therefore assist the researchers in the compilation of customer loyalty guidelines that reflect insight from both spheres of South Africa's emerging economy. Accordingly, the sample for the survey consisted of all individuals in Gauteng and North-West who had bought a financial services product from their independent financial adviser during the past 10 years. A decade was deemed suitable, given the fact that financial services products are generally not bought at regular intervals. The non-probability convenience sampling technique was applied, as a complete list of the population was not available.

The respondents were requested to rate a series of statements on a self-administered questionnaire using a five-point Likert scale, where 1 indicated 'strongly disagree' and 5 indicated 'strongly agree'. The questionnaire was adapted from scales that had previously been validated by Du Plessis (2010) and Van Vuuren (2011) in related studies amongst respondents in the insurance and optometric industries. The first part of the questionnaire gathered the demographic data of the respondents. The remaining part of the questionnaire comprised of a list of scales for the independent variables as well as the dependent variable customer loyalty.

Customer satisfaction was measured by including statements such as whether expectations have been met and if the respondent was treated in a professional manner; always received personalised attention from the financial adviser; believed the financial adviser was willing to listen to concerns; was treated as an individual; believed complaints have been resolved; believed that quality advice has been provided; and felt that the administrative service offered was of high quality.

Trust was measured by including statements such as if the respondents felt the financial adviser acted in their best interest; have confidence in the ability of the financial adviser 
to provide financial advice; and also believe the financial adviser is always honest with them; treats them with respect; is concerned with the management of their financial needs; acts in a way to cause them to trust him/her with their money; understand their needs; is highly skilled at his and/ or her job; and listens to them when they speak.

Supplier image was measured by testing whether the financial adviser's image was reflected by his experience to manage their financial needs; product knowledge to manage financial needs; the manner in which he and/or she adhere to financial legislation; the timeliness with which queries were addressed; and the professional manner in which service was provided to the respondent. It was further assessed whether the respondents would remain committed to the financial adviser because doing business with the practice has been worthwhile; annual adjustments were made to suit financial needs; and for the reasons that the financial adviser was flexible in serving customer needs; explained important concepts; has the customer's best interest at heart; and conducted a thorough analysis of financial needs.

Finally, customer loyalty was measured by testing if the respondents consider their financial adviser's practice as their first choice; would recommend the practice to others; intend to stay in a loyal relationship; believe the relationship is mutually beneficial; have no desire to change to another practice; encouraged other people to do business with the financial adviser; and would definitely buy financial products from the financial adviser in the future.

The validity of the study was attended to by ensuring that the content of the questionnaire supported the formulated research objectives and measured what the survey intended to measure. A pilot study involving 15 respondents who matched the sampling frame was also completed, and it verified that the design of the questionnaire would assist in meeting the research objectives of the study.

A total of 262 questionnaires were completed and could be used to analyse the results. After the data had been coded, captured and edited, SPSS version 18 was used to conduct the statistical analysis. Cronbach alphas were determined to assess the reliability of the scales used. Further statistical techniques employed included standard multiple regression analysis, independent sample t-tests and the one-way analysis of variance technique (ANOVA) and were used to test the four hypotheses formulated for the study.

\section{Results}

\section{Demographic profile of respondents}

The demographic profile of the respondents who participated in the study is summarised in Table 1.

It is evident from Table 1 that approximately a third (34.0\%) of the total number of respondents who participated in the study have been with their financial adviser's practice between two and five years. From a closer perspective, it
TABLE 1: Demographic profile of respondents.

\begin{tabular}{|c|c|c|c|}
\hline $\begin{array}{l}\text { Demographic } \\
\text { characteristic }\end{array}$ & $\begin{array}{c}\text { Total sample } \\
n=262\end{array}$ & $\begin{array}{c}\text { North-West province } \\
\qquad n=139\end{array}$ & $\begin{array}{c}\text { Gauteng province } \\
n=123\end{array}$ \\
\hline \multicolumn{4}{|c|}{ Number of years with financial adviser's practice } \\
\hline $0-2$ years & $22.9 \%$ & $14.4 \%$ & $32.5 \%$ \\
\hline $2-5$ years & $34.0 \%$ & $30.2 \%$ & $38.2 \%$ \\
\hline $5-10$ years & $20.6 \%$ & $24.5 \%$ & $16.3 \%$ \\
\hline More than 10 years & $19.5 \%$ & $25.2 \%$ & $13.0 \%$ \\
\hline No response & $3.1 \%$ & $5.8 \%$ & - \\
\hline \multicolumn{4}{|l|}{ Gender } \\
\hline Male & $48.1 \%$ & $43.2 \%$ & $53.7 \%$ \\
\hline Female & $49.2 \%$ & $51.8 \%$ & $46.3 \%$ \\
\hline No response & $2.7 \%$ & $5.0 \%$ & - \\
\hline \multicolumn{4}{|l|}{ Age group } \\
\hline $18-35$ years & $25.2 \%$ & $19.4 \%$ & $31.7 \%$ \\
\hline $36-47$ years & $41.6 \%$ & $46.0 \%$ & $36.6 \%$ \\
\hline $48-66$ years & $27.5 \%$ & $28.1 \%$ & $26.8 \%$ \\
\hline $67-82$ years & $1.5 \%$ & - & $3.3 \%$ \\
\hline Above 82 years & $0.4 \%$ & - & $0.8 \%$ \\
\hline No response & $3.8 \%$ & $6.5 \%$ & $0.8 \%$ \\
\hline \multicolumn{4}{|l|}{ Race } \\
\hline White people & $35.9 \%$ & $4.3 \%$ & $71.5 \%$ \\
\hline African & $51.1 \%$ & $86.3 \%$ & $11.4 \%$ \\
\hline Mixed race & $3.8 \%$ & $2.2 \%$ & $5.7 \%$ \\
\hline Indian/Asian & $5.7 \%$ & $0.7 \%$ & $11.4 \%$ \\
\hline No response & $3.4 \%$ & $6.5 \%$ & - \\
\hline
\end{tabular}

seems that the two to five years category also received the most responses in the North-West and Gauteng provinces. Table 1 further indicates that most of the respondents who participated in the survey in the North-West province were females $(51.8 \%)$, whilst the majority of the respondents who completed the questionnaire in the Gauteng province were males $(53.7 \%)$.

In both provinces, the age group 36-47 years was selected most. As the majority of the respondents who participated in the survey were older than 36 years, they were in a position to make a valuable contribution to the study, as individuals at this mature level generally tend to have clearly manifested perceptions and opinions about the industry and the products it offers.

Finally, most of the respondents in the North-West province are from the African population group (86.3\%), whilst the majority of the respondents from the Gauteng province are from the white racial group (71.5\%). Statistical analysis was conducted to determine if there would be a significant difference between the perceptions of the various racial groups. The results are discussed in the last part of the results section.

\section{Financial products purchased}

Table 2 provides an indication of the types of products that the respondents bought over the last 10 years. A 10-year period was selected as financial services products are not purchased on a frequent basis. The respondents were allowed to select more than one option, and generally it seems that the respondents who participated in the survey had been exposed to a variety of financial products. Overall though, 
TABLE 2: Financial products bought over the last 10 years.

\begin{tabular}{lccc}
\hline Financial product & $\begin{array}{c}\text { Total sample } \\
\boldsymbol{n = 2 5 8}\end{array}$ & $\begin{array}{c}\text { North-West province } \\
\boldsymbol{n}=\mathbf{1 3 5}\end{array}$ & $\begin{array}{c}\text { Gauteng province } \\
\boldsymbol{n}=\mathbf{1 2 3}\end{array}$ \\
\hline $\begin{array}{l}\text { Life insurance policy } \\
\text { Retirement annuity } \\
\text { policy }\end{array}$ & $55.8 \%$ & $44.4 \%$ & $68.3 \%$ \\
$\begin{array}{l}\text { Other investment } \\
\text { products }\end{array}$ & $24.7 \%$ & $36.3 \%$ & $30.9 \%$ \\
$\begin{array}{l}\text { Medical aid } \\
\begin{array}{l}\text { Short-term insurance } \\
\text { policy }\end{array}\end{array}$ & $24.0 \%$ & $34.8 \%$ & $16.3 \%$ \\
Other & $5.5 \%$ & $29.6 \%$ & $17.9 \%$ \\
\hline
\end{tabular}

a life insurance policy was the product bought most by the respondents $(55.8 \%)$, followed by a retirement annuity policy $(33.7 \%)$. The same pattern could be detected in each of the two provinces, but it seems that the life insurance policy category was selected more often in the Gauteng province $(68.3 \%)$ than in the North-West province (44.4\%).

\section{Reliability}

Table 3 portrays the Cronbach alphas that were calculated to determine the reliability of the scales used. The values per province as well as overall are all above 0.7 , which, according to Pallant (2010:97), can be deemed the minimum level of acceptable scale reliability. It can therefore be concluded that all five scales used in the survey were in fact reliable.

\section{The relationship between the selected variables and customer loyalty}

Standard multiple regression analysis was used to ascertain whether the selected variables can be viewed as predictors of customer loyalty towards independent financial advisers in the Gauteng and North-West provinces. The Pearson product-moment correlation coefficients were determined next, to explore the associations between the independent variables of trust, commitment, customer satisfaction, and supplier image and the dependent variable customer loyalty. It became evident from the results that overall all the constructs were significantly correlated the $p<0.05$ level. The same pattern could be detected at provincial level. Considering Pallant's (2010:134) guidelines, it seems that the

TABLE 3: Reliability statistics.

\begin{tabular}{lccc}
\hline Constructs & \multicolumn{3}{c}{ Cronbach's alpha } \\
\cline { 2 - 4 } & Total & Gauteng & North-West \\
\hline Trust & 0.947 & 0.952 & 0.934 \\
Commitment & 0.918 & 0.932 & 0.898 \\
Customer satisfaction & 0.919 & 0.932 & 0.902 \\
Supplier image & 0.897 & 0.891 & 0.888 \\
Customer loyalty & 0.960 & 0.971 & 0.943 \\
\hline
\end{tabular}

level of correlation of all the variables investigated was mostly medium to high, but not equal to or more than 0.9 , which would have demonstrated multicollinearity.

In the third step of the analysis, the researchers explored which of the independent variables included in the model contributed to the prediction of the dependent variable customer loyalty. The results are displayed in Table 4 .

The study relied on a $95 \%$ level of confidence in the interpretation of the results. Considering the findings from both provinces, the total variance explained by the model as a whole was $75.5 \%, F(5,242)=149.3, p<0.05$. The total variance explained by the model in Gauteng was somewhat higher, $80.8 \%, F(4,118)=124.188, p<0.05$ and lower in the North-West province, 67.8\%, $F(4,122)=64.291, p<0.05$.

It further appeared that in relation to the total sample, the variables commitment, customer satisfaction and supplier image have $p$-values of less than 0.05 and can consequently be regarded as predictors of customer loyalty. Within each of the two specific provinces a different scenario is, however, presented. In the Gauteng province only trust and commitment can be viewed as predictors of customer loyalty, as only their $p$-values were smaller than 0.05 . It further seems that when considering beta, the variance in customer loyalty explained by commitment (beta $=0.473, p<0.05$ ) is higher than the variance in customer loyalty that is accounted for by trust (beta $=0.249, p<0.05$ ). Within the North-West province, only the variable commitment seems to have a significant positive relationship with customer loyalty $(p=0.0001)$. When considering the beta value, one unit increase in commitment would result in a 0.594 increase in customer loyalty.

Consequently, following the above discussion, it is possible to conclude that $\mathrm{HA}^{1}$ should be rejected. Only trust and commitment can be viewed as predictors of customer loyalty in the Gauteng province and only commitment has a significant positive relationship with customer loyalty in the North-West province. Similarly, $\mathrm{HA}^{2}$ should then also be rejected, as not all variables appeared to have an equally significant positive relationship with customer loyalty.

\section{Significant differences between the perceptions of respondents in the Gauteng and North-West provinces}

Table 5 lists the mean values that were obtained for the four independent variables and the dependent variable customer loyalty. Considering the fact that a 5-point Likert scale was

TABLE 4: Regression model.

\begin{tabular}{|c|c|c|c|c|c|c|c|c|c|}
\hline \multirow[t]{2}{*}{ Independent variables } & \multicolumn{3}{|c|}{ Beta } & \multicolumn{3}{|c|}{$T$} & \multicolumn{3}{|c|}{ Sig. } \\
\hline & Total & Gauteng & North-West & Total & Gauteng & North-West & Total & Gauteng & North-West \\
\hline Trust & 0.116 & 0.249 & 0.039 & 1.387 & 2.290 & 0.317 & 0.167 & 0.024 & 0.752 \\
\hline Commitment & 0.547 & 0.473 & 0.594 & 8.051 & 5.189 & 5.740 & 0.0001 & 0.0001 & 0.0001 \\
\hline Customer satisfaction & 0.164 & 0.167 & 0.168 & 2.596 & 1.925 & 1.776 & 0.010 & 0.057 & 0.078 \\
\hline Supplier image & 0.106 & 0.063 & 0.090 & 2.135 & 1.086 & 1.291 & 0.034 & 0.280 & 0.199 \\
\hline
\end{tabular}

Dependent variable, Customer loyalty. 
TABLE 5: Comparison between perceptions of Gauteng and North-West respondents.

\begin{tabular}{|c|c|c|c|c|c|c|}
\hline \multirow[t]{2}{*}{ Variables } & \multicolumn{2}{|c|}{ Mean score } & \multirow[t]{2}{*}{$t$-value } & \multirow[t]{2}{*}{ Sig. } & \multirow{2}{*}{$\begin{array}{c}\text { Difference in } \\
\text { perception (G-N) }\end{array}$} & \multirow{2}{*}{$\begin{array}{l}\text { Ranking (based on } \\
\text { least difference) }\end{array}$} \\
\hline & Mean score Gauteng & Mean score North-West & & & & \\
\hline Trust & 3.90 & 3.53 & 3.93 & 0.0001 & 0.37 & 4 \\
\hline Commitment & 3.71 & 3.44 & 2.46 & 0.015 & 0.27 & 2 \\
\hline Customer satisfaction & 3.82 & 3.57 & 2.50 & 0.013 & 0.25 & 1 \\
\hline Supplier image & 4.19 & 3.79 & 4.92 & 0.0001 & 0.40 & 5 \\
\hline Customer loyalty & 3.70 & 3.39 & 2.46 & 0.014 & 0.31 & 3 \\
\hline
\end{tabular}

used to measure the various constructs, it appears that the respondents in both provinces were reluctant to agree with the statements formulated about their financial service providers. However, it also seems that the respondents in Gauteng had a slightly more positive perception of their financial advisers, given the fact that their mean scores (for all variables investigated) were higher than the mean scores for the respondents in the North-West province. Independent sample t-tests were then performed to verify whether the perceptions of the respondents in Gauteng were truly different from those of the respondents in North-West. A preliminary investigation was conducted first and confirmed that the data set complied with all the underlying assumptions for conducting the independent sample $t$-test.

The results of the independent sample $t$-tests then revealed that there are statistically significant differences between the perceptions of the respondents in the two different provinces with regard to all the variables investigated. More particularly, statistically significant decreases were detected in the following scores: trust (from Gauteng: $M=3.90$, SD $=0.78$ to North-West: $M=3.53, \mathrm{SD}=0.72 ; t(254)=3.93$, $p<0.05$ ), commitment (from Gauteng: $M=3.71, \mathrm{SD}=0.91$ to North-West: $M=3.44, \mathrm{SD}=0.80 ; t(253)=2.46, p<0.05)$, customer satisfaction (from Gauteng: $M=3.82, \mathrm{SD}=0.82$ to North-West: $M=3.57, \mathrm{SD}=0.77 ; t(255)=2.50, p<0.05)$, supplier image (from Gauteng: $M=4.19, \mathrm{SD}=0.67$ to NorthWest: $M=3.79, \mathrm{SD}=0.65 ; t(253)=4.92, p<0.05)$ and customer loyalty (from Gauteng: $M=3.70, \mathrm{SD}=1.08$ to North-West: $M=$ $3.39, \mathrm{SD}=0.90 ; t(250)=2.46, p<0.05)$. The mean decrease in scores displayed in Table 5 further shows that the difference in perceptions between the Gauteng and North-West respondents is largest with regard to the variable customer satisfaction.

The effect sizes calculated, using eta-squared, for all the variables listed in Table 5 are as follows: trust (0.057), commitment (0.023), customer satisfaction (0.024), supplier image (0.087) and customer loyalty (0.024). Considering these results and the guidelines provided by Pallant (2010:243), the actual difference in the mean scores between the groups can be regarded as relatively small with regard to the variables commitment, customer satisfaction and customer loyalty and moderate with reference to the variables trust and supplier image.

Following the above mentioned findings, it is possible to accept $\mathrm{HA}^{3}$

\section{Significant differences between the perceptions of the various racial groups}

ANOVA was used to investigate significant differences between the perceptions of the various racial groups. No further preliminary investigations were required because, as confirmed in the previous section, the study adhered to all the underlying assumptions for comparing groups. The findings are displayed in Table 6.

From Table 6 it is evident that there are statistically significant differences at the $p<0.05$ level between the perceptions of the different racial groups with regard to the variables trust, commitment and supplier image. Because some of the racial groups were relatively small, the researchers decided to also apply the Robust Test of Equality of Means in order to verify the differences in perceptions that were detected. The findings are displayed in the last two columns of Table 6 and confirm that at the $p<0.05$ level there are significant differences between the perceptions of the various racial groups with regard to the variables trust, commitment and supplier image.

Hochberg's test was performed next in order to determine the exact location of the differences in perceptions that were found. The test was deemed appropriate given the fact that the data obtained for these factors passed Levene's test for homogeneity of variance and the number of respondents interviewed from each racial group were not equal. The test confirmed that there were significant differences in perceptions between only the white and African population groups with regard to the variables trust $(p=0.004)$, commitment $(p=0.039)$ and supplier image $(p=0.0001)$. The effect sizes calculated, using eta-squared for each of the

TABLE 6: Test of homogeneity of variance, ANOVA and Robust Tests of Equality of Means, based on different racial groups.

\begin{tabular}{|c|c|c|c|c|c|c|c|c|}
\hline \multirow[t]{2}{*}{ Variables } & \multicolumn{4}{|c|}{ Test of homogeneity of variances $(p>0.05)$} & \multicolumn{2}{|c|}{ ANOVA $(p<0.05)$} & \multicolumn{2}{|c|}{ Robust tests of equality of means $(p<0.05)$} \\
\hline & Levene statistics & df1 & df2 & Sig. & $\boldsymbol{F}$ & Sig. & Brown-Forsythe statistics & Sig. \\
\hline Trust & 0.271 & 3 & 242 & 0.847 & 4.116 & 0.007 & 4.913 & 0.004 \\
\hline Commitment & 0.342 & 3 & 239 & 0.795 & 2.717 & 0.045 & 2.946 & 0.041 \\
\hline Customer satisfaction & 0.305 & 3 & 242 & 0.822 & 1.424 & 0.236 & 1.477 & 0.231 \\
\hline Supplier image & 0.259 & 3 & 241 & 0.855 & 10.077 & 0.0001 & 8.778 & 0.0001 \\
\hline Customer loyalty & 0.635 & 3 & 238 & 0.593 & 2.137 & 0.096 & 2.100 & 0.114 \\
\hline
\end{tabular}


variables, were respectively trust (0.029), commitment (0.024) and supplier image (0.052). Considering these results and the guidelines provided by Pallant (2010:254), the actual difference in the mean scores between the white and African racial groups can be regarded as relatively small.

Accordingly, following the above discussion, it can be concluded that $\mathrm{HA}^{4}$ can only be partially accepted. Significant differences were found between only the white and African racial groups, with respect to the variables trust, commitment and supplier image.

\section{Discussion}

Following the empirical results, a number of observations can be made.

Firstly, it seems that the respondents were well qualified to participate in the study. The majority of the respondents have been with their financial adviser's practice for longer than two years and are at a mature age when individuals generally have clearly manifested perceptions and opinions about the industry and the products it offers. It further appears that it is not necessary for financial advisers to differentiate their customer loyalty strategies based on racial discrepancies. The actual difference in the mean scores between the white and African racial groups was relatively small and does not warrant any customised strategies.

It can thirdly be observed that independent financial advisers in the Gauteng province should focus on trust and commitment when aiming to create more loyal clients for the business, as the $p$-values of only these two variables were smaller than 0.05. Financial advisers would, however, need to be careful in prioritising client commitment above the building of trusting relationships. Although the beta value for commitment (0.473) was higher than the beta value for trust (0.249), many scholars such as Morgan and Hunt (1994), Kuusik (2007), Negi and Ketema (2010) and Theron et al. (2012) have previously confirmed that trusting relationships must first be formed before clients will commit themselves to the business. Moreover, given the fact that both variables could assist in fostering customer loyalty, financial advisers should rather focus on building commitment with their clients within a trusting environment.

The fourth observation that can be made is that only the variable commitment seems to be a pertinent predictor of customer loyalty in the North-West province and not trust or any other of the variables investigated. This is an interesting finding, given the importance of trust in forming relationship commitment and because no evidence of multicollinearity could be found between the variables trust and commitment (the Pearson product-moment correlation coefficient was lower than 0.9). In light of the work of previous scholars on this topic (Hunt et al. 2006; Morgan \& Hunt 1994; Rauyruen \& Miller 2007; Theron \& Terblanche 2010; Theron, Terblanche \& Boshoff 2010a; Theron et al. 2010b; Van Vuuren 2011) it is advisable that the variable trust should still be regarded as instrumental in building commitment. However, once a committed relationship has been established, independent financial advisers in the North-West province might also need to explore additional factors (not identified by this study) that could assist in creating more loyal clients for their businesses.

The fifth observation that can be derived from the findings is that it seems the performance of the independent financial advisers in Gauteng was superior to the performance of the financial advisers in North-West. The mean scores for the advisers in Gauteng (with regard to all the variables investigated) were significantly higher than the mean scores for the respondents in North-West. The success of the independent financial advisers in Gauteng could be attributed to the fact that they have had more access to training and the mediums required to deliver a proficient service than the advisers in North-West. Accordingly, independent financial advisers in North-West might benefit from studying the success stories of the advisers in Gauteng, especially concerning the building of trusting relationships and the improvement of their supplier image, where a moderate difference was detected.

Finally, it seems that there are also other factors that could assist in predicting customer loyalty towards independent financial advisers which must be further explored. The total variance explained by the model in Gauteng was $80.8 \%$ and in North-West only $67.8 \%$.

\section{Theoretical and practical implications}

Firstly, our research results suggest that the CommitmentTrust theory of Morgan and Hunt (1994) can no longer be perceived as the base of departure for all supplier-customer relationships in a business-to-consumer (B2C) environment. These two authors argued that both trust and commitment are two core factors of relationship marketing because they encourage marketers to remain invested within a relationship. However, our research findings challenge the seminal work of Morgan and Hunt by establishing that in South Africa, the extent to which trust and commitment predicts relationship loyalty is specific to both industry and geographical location. In the Gauteng province, it was established that both trust and commitment can be perceived as predictors of customer loyalty. However, in the North-West province it was determined that loyalty could result from commitment alone. In a semi-urban environment, trust is therefore not perceived as a prerequisite to secure customer loyalty but is relevant in establishing a relational approach to customer management. This finding is supported by Theron et al. (2012:31), who state that ' ... it is possible to build commitment without the presence of trust'. Theron et al. (2010b:1005) further established that financial services decision makers do not necessarily perceive trust as a factor that influences commitment in the relationship-building process. They established that both parties to a relationship (namely the financial service provider and the client) should be motivated to make an investment of time and other resources to secure the continuation of the relationship. The finding is valuable 
as it provides researchers with an initial understanding of what can be viewed as predictors of customer loyalty from both an urban and a semi-urban perspective.

Secondly, this study provides further understanding of the relationship between trust, commitment and customer loyalty from both an urban and a semi-urban perspective. Theoretical arguments on the variables required to strengthen customer loyalty are provided from a financial services environment perspective. The theoretical approach followed in the article guides independent financial advisers on relational success. It stipulates that to succeed in an evolving market environment, it would be imperative for advisers to build good relationships with their clients and ensure that they remain loyal to them over the long term. Such a relational focus should, however, be adjusted for either an urban or a semi-urban context, depending on the geographical location in which the relationship is built. Therefore, by understanding the factors influencing customer loyalty (trust, commitment, customer satisfaction and supplier image), the relationship marketing approach of the independent financial adviser could be aimed at improving customer loyalty initiatives, ultimately increasing the use of financial planning services.

\section{Limitations and implications for future research}

The survey conducted for this article provided valuable information regarding the factors of relationship marketing that do predict customer loyalty in the independent financial adviser environment of both the Gauteng and North-West provinces. The empirical findings should, however, be considered within the context of some limitations to the study. Firstly, the study applied convenience sampling and interviewed respondents from only the Gauteng and NorthWest provinces. The results can therefore not be generalised to South Africa as a whole. A future research study would need to be conducted on a broader scale and should include a representative proportion of all the provinces of South Africa that is inclusive of both urban and semi-urban areas. Secondly, a mixed-method approach that includes both quantitative and qualitative research techniques could be followed to provide more insight into the respondents' perceptions of their financial advisers, and understanding of the true motivation behind the clients' desire to remain loyal towards their financial advisers.

\section{Conclusion}

The purpose of this study was to develop guidelines for creating customer loyalty towards independent financial advisers in South Africa. The empirical findings revealed that in the Gauteng province, relationships based on both trust and commitment might secure customer loyalty. In the North-West province it was, however, determined that only commitment might lead to customer loyalty. In terms of race, the results illustrate that significant differences could be found between only the white and African race groups. However, these differences were so small that they do not warrant any customised strategies
Ultimately, the findings of this study contribute to an understanding of the trust-commitment relationship theory within the financial services environment of South Africa. The study further offers more direction to independent financial advisers in building relationships with their clients that will last over the long term.

\section{Acknowledgements Competing interests}

The authors declare that they have no financial or personal relationship(s) which may have inappropriately influenced them in writing this article.

\section{Authors' contributions}

E.v.T. and M.R.-L. equally contributed to the research and writing of this article.

\section{References}

Abdul-Muhmin, A.G., 2005, 'Instrumental and interpersonal determinants of relationship satisfaction and commitment in industrial markets', Journal of Business Research 58(5), 619-628. http://dx.doi.org/10.1016/j.jbusres.2003. 08.004

Amin, G., Almani, M., Pournaserani, A. \& Mousavian, S.J., 2011, 'Relationship marketing: A new approach to marketing in the third millennium', Australian Journal of Basic and Applied Sciences 5(5), 787-799.

Amoako, G.K., 2012, 'Improving customer service in the banking industry - case of Ghana Commercial Bank (GCB) - Ghana', International Business Research 5(4), 134-148. http://dx.doi.org/10.5539/ibr.v5n4p134

Balas, A. \& Tareef, F., 2011, 'Implementing customer focused service concept in auto workshops in Israel', in Marketing from information to decision, 4th edn., International Conference on Marketing, Cluj-Napoca, Romania, October 28-29, 2011.

Da Silva, R.V. \& Alwi, S.F., 2008, 'Online corporate brand image, satisfaction and loyalty', Journal of Brand Management 16(3), 119-144. http://dx.doi.org/ 10.1057/palgrave.bm.2550137

Du Plessis, L., 2010, 'Customer relationship management and its influence on customer loyalty at Liberty Life in South Africa', MCom dissertation, University of Johannesburg, South Africa.

Dwyer, R.F., Schurr, P.H. \& Oh, S., 1987, 'Developing buyer-seller relationships', Journal of Marketing 51, 11-27. http://dx.doi.org/10.2307/1251126

Ebersohn, R. \& Theron, E., 2014, 'Trust in an unwanted service environment: The case of pregnancy termination counselling services', Acta Commercii 14(1), 1-8. http:// dx.doi.org/10.4102/ac.v14i1.233

Egan, J., 2011, Relationship marketing: Exploring relational strategies in marketing, 4 th edn., Pearson Education, Harlow.

Friedman, D.C., Brown, T.A. \& Taran, Z., 2007, 'Specialty store expertise as a driver of satisfaction and share of wallet', The International Review of Retail, Distribution and Consumer Research 21(4), 375-389. http://dx.doi.org/10.1080/09593969. 2011.595497

Gilaninia, S., Mohammadi, A.A., Pournaserani, A. \& Javad, S., 2011, 'Relationship marketing: A new approach to marketing in the third millennium', Australian Journal of Basic and Applied Sciences 5(5), 787-799.

Gounaris, S.P., 2005, 'Trust and commitment influences on customer retention: Insights from business-to-business services', Journal of Business Research 58(2), 126-140. http://dx.doi.org/10.1016/S0148-2963(03)00122-X

Ha, S.H. \& Lee, M.J., 2010, 'Customer service quality improvement in the public sector through the Internet', Total Quality Management 21(11), 1161-1176. http:// dx.doi.org/10.1080/14783363.2010.529341

Halimi, A.B., Chavosh, A. \& Choshali, S.H., 2011, 'The influence of relationship marketing tactics on customer's loyalty in B2C relationships - the role of communication and personalisation', European Journal of Economics, Finance and Administrative Sciences 31, 1450-2275.

Harwood, T., Garry, T. \& Broderick, A., 2008, Relationship marketing: Perspectives, dimensions and contexts, McGraw-Hill, Maidenhead.

Hawabhay, B.B., Abratt, R. \& Peters, M., 2009, 'The role of corporate communications in developing a corporate brand image and reputation in Mauritius', Corporate Reputation Review 12(1), 3-20. http://dx.doi.org/10.1057/crr.2009.4

Hennig-Thurau, T., Gwinner, K.P. \& Gremler, D.D., 2002, 'Understanding relationship marketing outcomes: An integration of relationship benefits and relationship quality', Journal of Services Research 4(3), 230-247. http://dx.doi.org/10.1177/ 1094670502004003006 
Hoq, M.Z., Sulatana, N. \& Amin, M., 2010, 'The effect of trust, customer satisfaction and image on customers' loyalty in Islamic banking sector', South Asian Journal of Management 7(1), 70-93.

Hu, H., Kandampully, J. \& Juwaheer, T.D., 2009, 'Relationships and impacts of service quality, perceived value, customer satisfaction, and image: An empirical study', Service Industries Journal 29(2), 111-125. http://dx.doi.org/10.1080/ 02642060802292932

Hunt, S.D., Arnett, D.B. \& Madhavaram, S., 2006, 'The explanatory foundations of relationship marketing theory', Journal of Business \& Industrial Marketing 21(2), 72-87. http://dx.doi.org/10.1108/10610420610651296

Joffe, H., 2010, 'Financial planning - consider the psychology of people's lives when giving financial advice', Enterprise Risk 4(7) August, 4-5

Johnson, D. \& Grayson, K., 2005, 'Cognitive and affective trust in service relationships', Journal of Business Research 58(4), 500-507. http://dx.doi.org/10.1016/S01482963(03)00140-1

Jumaev, M., Kumar, D. \& Hanaysha, J.R.M., 2012, 'Impact of relationship marketing on consumer loyalty in the banking sector', Far East Journal of Psychology and Business 6(3), 36-55.

Kuo, Y. \& Ye, K., 2009, 'The causal relationship between service quality, corporate image and adults' learning satisfaction and loyalty: A study of professional training programmes in a Taiwanese vocational institute', Total Quality Management and Business Excellence 20(7), 749-762. http://dx.doi.org/10.1080/ 14783360903037085

Kuusik, A., 2007, Affecting customer loyalty: Do different factors have various influences in different loyalty levels?, Faculty of Economics \& Business Administration Working Paper Series, 58, University of Tartu, pp. 3-9.

Leisen, B. \& Hyman, M.R., 2004, 'Antecedents and consequences of trust in a service provider: The case of primary care physicians', Journal of Business Research 57(9), 990-999. http://dx.doi.org/10.1016/S0148-2963(02)00343-0

Liang, C.J. \& Wang, W.H., 2007, 'An insight into the impact of a retailer's relationship efforts on customers' attitudes and behavioral intentions', International Journal of Bank Marketing 25(5), 336-366. http://dx.doi.org/10.1108/02652320710772998

Luo, X. \& Homburg, C., 2007, 'Neglected outcomes of customer satisfaction', Journal of Marketing 71(2), 133-149. http://dx.doi.org/10.1509/jmkg.71.2.133

Morgan, R.M. \& Hunt, S.D., 1994, 'The commitment-trust theory of relationship marketing', Journal of Marketing 58, 20-38. http://dx.doi.org/10.2307/1252308

Ndubisi, N.O., Malhotra, N.K. \& Chan, K.W., 2009, 'Relationship marketing, custome satisfaction and loyalty: A theoretical and empirical analysis from an Asian perspective', Journal of International Consumer Marketing 21(1), 5-8. http://dx. perspective', Journal of International Con
doi.org/10.1080/08961530802125134

Ndubisi, N.O., Wah, C.K. \& Ndubisi, G.C., 2007, 'Supplier-customer relationship management and customer loyalty: The banking industry perspective', Journal of Enterprise Information Management 20(2), 222-236. http://dx.doi.org/10.1108/ Enterprise Information
17410390710725797

Negi, R. \& Ketema, E., 2010, 'Relationship marketing and customer loyalty: The Ethiopian mobile communication perspective', International Journal of Marketing Management 5(1), 113-124.

Nijssen, E.J. \& Van Herk, H., 2009, 'Conjoining international marketing and relationship marketing: Exploring consumers'cross-border service relationships', Journal of International Marketing 17(1), 91-115. http://dx.doi.org/10.1509/jimk.17.1.91

Nyadzayo, M., 2010, 'The mediating role of customer relationship management on customer retention at selected motor vehicle dealership in the Buffalo City Municipality', MCom dissertation, University of Fort Hare, South Africa.

Oliver, R.L., 1997, Satisfaction: A behavioral perspective on the consumer, McGraw Hill, New York.

Omar, M.W. \& Moh, M.N., 2010, 'Brand loyalty and relationship marketing in Islamic banking system', Canadian Social Science 6(1), 25-52.

Pallant, J., 2010, SPSS survival manual, McGraw-Hill, Maidenhead.

Rai, A.K. \& Medha, S., 2013, 'The antecedents of customer loyalty: An empirical investigation in life insurance context', Journal of Competitiveness 5(2), 139-163. http://dx.doi.org/10.7441/joc.2013.02.10
Rauyruen, P. \& Miller, K.E., 2007, 'Relationship quality as a predictor of B2B customer loyalty', Journal of Business Research 60(1), 21-31. http://dx.doi.org/10.1016/j. jbusres.2005.11.006

Razzaque, M.A. \& Boon, T.G., 2003, 'Effects of dependence and trust on channel satisfaction, commitment and cooperation', Journal of Business-to-Business Marketing 10(4), 23-48. http://dx.doi.org/10.1300/J033v10n04_02

Read, B., 2009, 'Top tips to build and keep customer loyalty with CRM', Customer Inter@ction Solutions 27(9), 26-28.

Roberts, B., Struwig, J., Gordon, S., Viljoen, J. \& Wentzel, M., 2012, 'Financial literacy in South Africa: Results of a baseline national survey 2012', Financial Services Board (FSB), Johannesburg.

Rootman, C., Tait, M. \& Sharp, G., 2011, 'Relationship marketing and customer retention lessons for South African banks', South African Business Review 15(3), 184-206.

Soureli, M., Lewis, B.R. \& Karantinou, K.M., 2008, 'Factors that affect consumers' cross-buying intention: A model for financial services', Journal of Financial Services Marketing 13(1), 5-16. http://dx.doi.org/10.1057/fsm.2008.1

South Africa Info, 2013, South Africa 'two-thirds urbanised', viewed 26 October 2015, from http://www.southafrica.info/news/urbanisation-240113.htm\#.ViAeUiUCpo.

South Africa Info, 2015a, 'Gauteng province, South Africa', viewed 27 October 2015 from http://www.southafrica.info/about/geography/gauteng.htm\#.Vi-DjU1UCpo.

South Africa Info, 2015b, 'North-West province, South Africa', viewed 27 October 2015, from http://www.southafrica.info/about/geography/north-west.htm\#.ViDjU1UCpo.

Struwig, J., Roberts, B. \& Gordon, S., 2013, Financial literacy in South Africa 2013 report, Human Sciences Research Council (HSRC), Cape Town.

Swar, B.N., 2012, 'Managing customers' perceptions and expectations of service delivery in selected banks in Odisha', The Indian Journal of Management 5(2), 25-33.

Tellefsen, T. \& Thomas, G.P., 2005, 'The antecedents and consequences of organizational and personal commitment in business service relationships', Industrial Marketing Management 34(1), 23-37. http://dx.doi.org/10.1016/j. indmarman.2004.07.001

Theron, E. \& Terblanche, N.S., 2010, 'Dimensions of relationship marketing in business-to business financial services', International Journal of Market Research 53(3), 31-52. http://dx.doi.org/10.2501/s1470785310201326

Theron, E., Terblanche, N.S. \& Boshoff, C., 2010a, 'Trust, commitment and satisfaction: New perspectives from business-to-business (B2B) financial services relationships in South Africa', paper presented at the Australian and New Zealand Marketing Academy (ANZMAC) Conference, Auckland, New Zealand.

Theron, E., Terblanche, N.S. \& Boshoff, C., 2010b, 'The antecedents of relationship commitment in the management of relationships in business-to-business (B2B) financial services', Journal of Marketing Management 24(9/10), 997-1010.

Theron, E., Terblanche, N.S. \& Boshoff, C., 2012, 'A managerial framework fo relationship management in the business-to-business financial services industry', Management Dynamics 21(4), 31-52.

Van Vuuren, T., 2011, 'Customer loyalty in an optometric practice - a case study perspective', MCom dissertation, University of Johannesburg, South Africa.

Van Vuuren, T., Roberts-Lombard, M. \& Van Tonder, E., 2012, 'The relationship between selected variables and customer loyalty within an optometric practice environment', Acta Commercii 12(1), 94-106.

Venetis, K.A. \& Ghauri, P.N., 2004, 'Service quality and customer retention: Building long-term relationships', European Journal of Marketing 38, 1577-1598. http:// dx.doi.org/10.1108/03090560410560254

Wang, C., 2010, 'Service quality, perceived value, corporate image, and customer loyalty in the context of varying levels of switching costs', Psychology and Marketing 27(3), 252-262. http://dx.doi.org/10.1002/mar.20330

Zuma, N., 2013, 'Rural-urban migration in South Africa', paper presented at the Economic Policy Forum for growth, transformation, reform: Emerging economies in the next decade, Haikou, China, 1-2 November. 